\title{
LIS education and training in South Africa: a historical review
}

\author{
J. Raju \\ Department of Library and Information Studies, Durban Institute of Technology, M.L. Sultan Campus, P.O. Box \\ 1334, Durban, 4000, Republic of South Africa \\ jayar@dit.ac.za
}

\begin{abstract}
Received: $28^{\text {th }}$ October 2003
Revised: $19^{\text {th }}$ May 2004

The article aims to provide a more complete historical review of LIS education and training in South Africa, particularly the involvement of technikons as well as how changes in the post-1990 era in South African society generally and in the higher education sector specifically, have impacted on LIS education and training.
\end{abstract}

Keywords: LIS education and training-South Africa; LIS education and training-South Africa-History

\section{Introduction}

The purpose of this article is to provide a historical review of library and/or information science (LIS) education and training in South Africa. It is deemed necessary to update the historical development of LIS education and training in South Africa, as the last time this was done was when Van Brakel (1992) reported on a survey undertaken in the early 1990s among universities in South Africa offering LIS education and training. Furthermore, since 1992 there have been dramatic changes in South African society generally and in the higher education sector specifically, that have impacted on LIS education and training in South Africa. Also, previous writings on this subject have largely focussed on the university context. Technikon LIS education and training has in more recent years emerged as a significant development. These new trends and developments need to be incorporated into an updated account of the historical development of LIS education and training in South Africa.

\section{Early history}

According to Musiker (1986: 91) LIS education and training in South Africa had its beginnings in 1933 when the professional body, South African Library Association (SALA) as it was known then, introduced correspondence courses for the training of librarians following the 1928 recommendations of the Carnegie Corporation commissioners S.A. Pitt and M.J. Ferguson. Prior to 1933 librarians obtained overseas, mostly British, qualifications via correspondence as had happened in most of Africa (Rosenberg 1999). SALA, following very much the British model, offered courses and examinations in librarianship. In 1962 the professional body transferred responsibility for correspondence courses to the University of South Africa that had come to be established as South Africa's correspondence university. However, SALA, which subsequently became the South African Institute for Librarianship and Information Science (SAILIS) continued its involvement in education and training in librarianship through its Committee for Education and Research that had been involved in drawing up standards and guidelines for the education and training of librarians in South Africa.

The University of Pretoria became the first university to offer a programme in librarianship in 1938 and a year later, the University of Cape Town followed it. The University of South Africa began correspondence programmes in librarianship in 1955. There was a proliferation of university education and training programmes in librarianship in the years that followed (Musiker 1986: 91). The university qualifications offered included a two-year Lower Diploma in Librarianship that provided training of a paraprofessional nature. Professional training was obtained via a one-year Postgraduate Diploma in Librarianship (taken after completion of a three-year bachelor's degree) or a four-year Bachelor of Library and Information Science, also known as the Baccalaureus Bibliothecologiae (B.Bibl.). There were also advanced qualifications at honours, masters and doctoral levels (Kerkham 1988: 7).

\section{Professional and paraprofessional education and training}

It was clearly a departure from international trends that both paraprofessional and professional training in librarianship were being offered at universities in South Africa. Rosenberg (1999: 14) indicates that this happened in other African countries as well but as educational facilities developed in these countries, paraprofessional programmes had been passed on to non-university institutions. According to Kerkham (1988:7) the late 1970s saw an increasing focus on the need for the professionalisation of librarianship and information science in South Africa and a clear distinction began to be drawn between professional librarians and information workers with a three-year degree plus Post-graduate Diploma or a fouryear B.Bibl., paraprofessional library and information workers with a Lower Diploma, and clerical and administrative staff with a school leaving certificate. At this time universities began phasing out all programmes of a sub-degree standard and 
this included the Lower Diploma in Librarianship. The gap in paraprofessional training left here was to be filled by technikon offerings in LIS education and training that are discussed later in this article. Thus professional LIS education and training in South Africa became established in universities at the degree level as was the international trend (Stieg 1992; Rochester 1997).

SALA's Committee for Education and Research in 1979 developed the Standards for library and information service that "guided universities for many years in their curriculum developing stages" (Van Brakel 1992: 188). The first set of standards was developed in 1948 and was subsequently replaced by a set developed in 1964 (South African Institute for Librarianship and Information Science 1987: I). In its 1987 Standards for education for library and information science SAILIS (through its Committee for Education and Research which later became the Committee for Formal Education) continued to assume responsibility for the advancement of education and training in library and information science and recognised a professional as well as a paraprofessional level in education and training in library and information science:

A professional level, which shall provide for the education of staff capable of exercising professional tasks in the library and information service and of assuming responsibility in middle-management...;

A paraprofessional level, which shall provide for training of staff with the knowledge and competence required for the handling of standard library and information techniques, procedures and appliances in a prescribed manner.

(South African Institute for Librarianship and Information Science 1987: 4)

The 1987 SAILIS Standards also made it very clear that education and training in library and information science at the professional level must be offered at a university thus firmly establishing in South Africa the international trend of LIS education and training being located in universities.

\section{The literature}

A survey undertaken in the early 1990s by Van Brakel (1992: 189) among eleven universities in South Africa offering LIS education and training, reported variations in the official names of academic departments. Some of these variations included: School of Librarianship, Department of Library and Information Science, Department of Information Science and Department of Information Studies. Van Brakel pointed that while these might serve to indicate the teaching specialities of the departments, in some cases it seems as if it is merely a matter of keeping up with the new international trend of reflecting the new emphasis on information. Nassimbeni (1988: 155) comments that the terminological trend of the word 'information' replacing the word 'library' and its derivative forms in the names of library schools, journals and professional organisations, has become particularly noticeable in the United States of America, the United Kingdom as well as in South Africa. Stilwell (1997: 207) comments that the core curricula of the various LIS education and training departments in South Africa have "varying emphases between library and information studies on the one hand and information science on the other". Underwood and Nassimbeni (1996: 219) see these differences of emphasis in the curricula offered as an exploration of the "distinction, if any, between library science and information science" and "South Africa is not unique in exploring this issue... [it is] typical of many other countries". Underwood and Nassimbeni (1996: 219) go on to point out that "a recent effect of this difference in emphasis is a change in nomenclature by some institutions for their departments and degrees to emphasise 'information' instead, or to the exclusion, of 'library".

The 1992 report of the National Education Policy Investigation (NEPI) Library and Information Services Research Group highlighted a number of areas that needed to be addressed in LIS education and training in South Africa. Some of these included the lack of differentiation and specialisation among teaching departments, the lack of articulation of programmes between institutions that results in limited mobility, and curriculum offerings that neglect the local and African context (National Education Policy Investigation 1992: 38).

Nassimbeni, Stilwell and Walker (1993: 31) have commented on the issue of differentiation and specialisation among teaching departments by stating that apart from a tendency among many universities to move towards an emphasis on 'information science', there are few options for specialisations in other areas. The IFLA Mission to South Africa (International Federation of Library Associations and Institutions 1994: 6I) commented on the fact that first level LIS education and training in South Africa tends to be deliberately broad-based in order to enable professionals to find employment in a variety of LIS services organisations. Van Brakel's 1992 survey of LIS teaching departments referred to above, also revealed very little specialisation at the basic professional qualification level and recommended that university LIS departments "ought to specialise according to their unique environments, for example, commercial/business environment, museums, information technology, public libraries, community information services, and so forth" (Van Brakel 1992: 190). The example of the Library and Information Science Department at the University of the North that is situated in a rural area and specialises in information services for agriculture, is cited. The SAILIS Proposed guidelines for undergraduate career training also encouraged specialisation at the level of basic professional qualifications (South African 
Institute for Librarianship and Information Science 1996: 3). Underwood and Nassimbeni (1996: 219-220) have commented that the range of specialisation offered by the LIS education and training sector in South Africa is small with school librarianship being the main area of specialisation. They believe that this is a reflection of a general debate over whether the function of LIS education is best served by supplying generalist programmes or a range of sharply differentiated programmes leading to different career paths. It seems that the general lack of specialisation at the basic qualification level in LIS in South Africa has been lamented and there has been much encouragement for such specialisation to occur. The more recent study by Raju (2002) has attempted to investigate this issue and reports findings regarding the current state of specialisation at the basic qualification level in LIS in South Africa.

With regard to the articulation of LIS programmes between institutions, Nassimbeni, Stilwell and Walker (1993: 3I) have pointed out that because of the absence of linkages between institutional types, student mobility is restricted. The IFLA Mission to South Africa, reported a similar conclusion saying that the current LIS education and training situation in South Africa is such that it promotes little or no standardisation between technikon and university based qualifications. However, the author would like to point out that the transformation that higher education in South Africa is currently undergoing, especially the development of the National Qualifications Framework (NQF), would hopefully establish the necessary linkages between higher education institutions to promote the articulation of LIS programmes between institutions and the mobility of students generally.

The issue, raised by the NEPI report, of curriculum offerings in South African LIS education and training that neglect the local and African context has been commented on several times over the years. Zaaiman (1985: 136) identified the domination of ideas emanating from the West as a deficiency in LIS education and training in South Africa. Nassimbeni, Stilwell and Walker (1993: 3I) have commented that progressive LIS services workers have expressed concern that most curricular offerings in South Africa "assume inappropriate Anglo-American models and fail to address the realities of the current library and information infrastructure in South Africa". Manaka (1990: 43) and Underwood (1996: 147) have also commented on the need to take cognisance of indigenous culture in LIS education and training. It is evident that as in the case of the rest of Africa (Rosenberg 1999), in South Africa too, the need to indigenise LIS curricula has been recognised. It is the author's opinion, based on personal and professional experience, that there have been attempts by LIS departments or programmes to heed the calls for greater African content in LIS curricula, but obviously with varying degrees of success among the different LIS departments or programmes.

Technological imperatives in South Africa, like in other parts of the world, have called for and led to curricular revisions in LIS education and training. There seems to be a general fear among LIS departments or schools (locally and internationally) that if they do not respond to technological change by making appropriate innovations to the curriculum, other bodies or academic departments, for example, Computer Science, will meet the challenge. The SAILIS Proposed guidelines for undergraduate career training acknowledged that "it is becoming increasingly difficult to restrict the training area to (traditional) library work". It therefore recommended that professional subjects in under-graduate education and training "should be placed in broader social, cultural, political and economic contexts by including related fields of information work" such as "information management, information technology management and other specialised information work" (South African Institute for Librarianship and Information Science 1996: I). Ocholla (2000: 37-38), in a comparative overview of LIS education and training in Africa in which he remarks that "in this new millennium, disregard for technological and market place forces...is suicidal" (again demonstrating the fear of LIS departments or schools mentioned above), cites South Africa as an example of where most LIS education and training curricula have undergone revision to keep abreast with new developments. It is the author's opinion that while most LIS departments or programmes in South Africa have attempted to expose students to a variety of applications in information technology, this has been done with varying degrees of success with education and training institutions' ability to provide the required IT resources being a crucial factor here.

Nassimbeni (1988: 168) remarks that despite differences in terminology and variations in emphases there has been considerable uniformity among the curricula offered by the various LIS departments or programmes in South Africa. This is because the SAILIS 1987 Standards for education for library and information science had laid down the major elements of study (the common core) for basic professional education and training, which LIS departments or programmes were obliged to represent adequately and appropriately in their curricula. The SAILIS Committee for Formal Education evaluated professional curricula according to the precepts outlined in the Standards for education for library and information science. In this way SAILIS played an accrediting role in LIS education and training in South Africa very much like the professional bodies have done in the international LIS scene (Stieg 1992; Rochester 1997; Rosenberg 1999).

SA Jnl Libs \& Info Sci 2005, 7I(I) 


\section{Professional bodies and accreditation}

LIS graduates were able to attain full professional membership of SAILIS after serving two years of practical experience under the supervision of a professional librarian or information worker and upon acceptance of their applications for professional membership. As a national professional accreditation body SAILIS had no statutory powers but was able to influence employment opportunities in established LIS services organisations. For example, it was not unusual for advertisements for professional posts to require SAILIS professional membership as a preference (International Federation of Library Associations and Institutions 1994: 62). In the late 1990s SAILIS was dissolved, and the Library and Information Association of South Africa (LIASA) was launched in 1997 as the new professional body in the LIS sector (Library and Information Association of South Africa 1997: I). Accreditation has been in abeyance since the early 1990s because new educational guidelines were being discussed within SAILIS (Nassimbeni, Stilwell and Walker 1993: 32). The new guidelines (Proposed guidelines for undergraduate career training) emerged in 1996 at a time when there were dramatic changes taking place in South African society generally and in higher education specifically. SAILIS' Committee for Formal Education that was responsible for compiling the Guidelines indicated that in view of the changes currently taking place in South Africa, especially policy that was evolving at the macro-level in higher education, it was not possible to present standards but only guidelines "limited to those matters over which the training institutions have a measure of control". These Guidelines were to serve as an "interim measure to provide assistance to all training units" (South African Institute for Librarianship and Information Science 1996: I, 3-4). This (and the fact that SAILIS was winding down its activities in preparation for the launch of LIASA and the dissolving of SAILIS by the late 1990s) could possibly explain why suspension of accreditation of LIS education and training programmes continued even after the emergence of the 1996 Guidelines. However, more importantly accreditation is likely to remain in abeyance until SGBs (Standards-Generating Bodies), NSBs (National Standards Bodies), ETQAs (Education and Training Quality Assurers) and other new structures for standards generation and accreditation of programmes for the LIS education and training sector become fully operational. As with education and training in other fields, standards generation and accreditation of programmes in the LIS education and training sector will now fall under the ambit of the South African Qualifications Authority (SAQA) and its National Qualifications Framework but with the involvement of professional bodies, LIS education and training providers and other stakeholders in the LIS services field.

\section{The Bunting review}

In 1988 the Academic Planning Committee (APC) of the Committee of University Principals (CUP) undertook a national review of academic programmes in librarianship and information science. This review stemmed from general government concerns about the duplication of services by universities (Bunting 1990). The CUP released the final report of the review committee in 1990 (Bunting 1990). The report is commonly referred to in the literature as the Bunting report or the Bunting recommendations after the chair of the review committee. The review committee arrived at the general conclusion that librarianship programmes in universities in South Africa must be rationalised. Recommendations included closure of certain departments, some departments curtailing programmes offered and other departments developing their current programmes (Committee of University Principals 1990: 9; 21-27).

The national review of academic programmes in librarianship and information science resulted in the closing of the library school at the University of the Witwatersrand, some departments curtailing their programmes and other departments mandated to retain and develop post-graduate programmes (Nassimbeni, Stilwell and Walker 1993: 32, 36). Van Brakel's (1992: 191-192) survey of universities in South Africa offering LIS education and training, indicated that the Bunting recommendations "had not had much effect on LIS training in South Africa" as only a few direct changes were reported. Van Aswegen (1997: 54) points out that not all universities heeded the recommendations of the Bunting report. The CUP made it clear that these recommendations were merely recommendations and that 'individual universities' autonomy is fully respected and the decision on closing or scaling down of any academic activity of the universities fully rests with respective Senates and Councils" (Brink 1991: 7).

However, Van Brakel warned in his 1992 survey that the Bunting investigation will, perhaps in another guise, rear its head in the future and this time with more binding effect and drastic actions such as reduced subsidies being implemented. And indeed it has, and this time in the form of the National Plan to restructure the higher education system in South Africa to overcome inequalities and inefficiencies of the past. In fact the recent Approved academic programmes for universities and technikons : 2003-2006 document that gives effect to aspects of the National Plan, has specifically called for a review of programmes that are duplicated in certain regions (Ministry of Education 2002), LIS programmes in the province of Kwazulu Natal being among these.

The NEPI Library and Information Services Research Group (National Education Policy Investigation 1992: 37) expressed regret that the Bunting review committee was not able to include in its terms of reference an examination of 
the role of technikons in LIS education and training and the relationship between their programmes and those of the universities. For the same reason Underwood and Nassimbeni (1999: 186) believe that the conclusions of the Bunting review committee cannot be regarded as a "complete statement about the needs and demands for professional and paraprofessional education" in South Africa. In the author's opinion, the Bunting recommendations were useful to the extent that it assisted in reducing duplication in LIS education and training through closures and also in attempts to improve the quality of LIS academic programmes through recommending curtailment of some and strengthening of others (that is, if these recommendations were followed through). However, not including technikons in its review process has resulted in the erstwhile situation of duplication of LIS programmes re-emerging, with universities and technikons now both offering degrees up to doctoral level. It is thus not surprising that the Ministry of Education's Approved academic programmes for universities and technikons : 2003-2006 has called for a review of LIS programmes that are duplicated (Ministry of Education 2002).

\section{Technikons and paraprofessional LIS education and training}

According to Kerkham (1988: 7) the stage was set for technikons to develop a paraprofessional programme in LIS education and training when SALA published the 1979 Standards for education for library and information service. This document included a section on standards for the training of paraprofessional staff in libraries. It was also in the late 1970s, as mentioned earlier, that universities began to phase out the Lower Diploma in Librarianship that provided paraprofessional training in librarianship. This gap in paraprofessional training was filled by technikon offerings in LIS education and training as the late 1970s witnessed an increasing need for a "new category of library employee ... who would be fully conversant with modern office and information technology" (Kerkham 1988: 7). This is in keeping with international trends in LIS education and training where paraprofessional LIS programmes are located in non-university institutions (Bramley 1975; Rochester 1997; Rosenberg 1999).

The three-year National Diploma in Library and Information Services (which has undergone a few name changes and is today referred to as the National Diploma in Library and Information Studies), was first offered by Port Elizabeth Technikon in 1984, followed by the Cape Technikon in 1985, Pretoria Technikon and M.L. Sultan Technikon in 1986 and Natal Technikon in 1987, the last mentioned for a brief period only. Technikon South Africa (TSA) in 1992 began a correspondence (distance education) National Diploma that was aimed at individuals already employed in libraries (Van Aswegen 1997: 54). Van Aswegen points out that the technikon National Diploma "was in its infancy at the time of the Bunting debacle, resulting in recriminations from universities whose departments of LIS were threatened with closure". According to Bunting (1990: 58), at the time of the Bunting investigation there were eleven universities (excluding Rhodes University and the University of Durban-Westville which were winding down their activities for closure) and five technikons offering LIS education and training programmes.

According to Kerkham who was personally involved in developing the curriculum of the technikon National Diploma (Kerkham 1986: 3), in developing the curriculum cognisance was taken of library technician programmes overseas especially those in Canada and Australia. However, according to Kerkham, overseas curricula were not followed blindly, as it was necessary to develop a curriculum to suit the requirements of the South African situation. This included the guidelines set out in the SALA 1979 Standards for education for library and information service, requirements of the Department of National Education for registration of a National Diploma and the particular needs of South African libraries, which were becoming increasingly involved in modern information technology (Kerkham 1988: 9). Over the years this curriculum has undergone much re-curriculation involving input from all technikons offering the National Diploma as well as from Advisory Boards comprising both academics and practising librarians and information workers from all types of libraries and information services. All technikons in South Africa offering the National Diploma share the same co-operatively drawn up syllabus with up to thirty percent 'local content' permitted (Van Aswegen 1992: 20). The minimum admission requirement for the National Diploma is a senior certificate (school leaving certificate) or its equivalent. Matriculation exemption is not necessary unlike with the university based first level LIS education and training programmes that do require the general university admission requirement, which is a matriculation exemption (South African Institute for Librarianship and Information Science 1987: 7, 12). Some technikons also require as part of the admission requirements the successful completion of an English language comprehension test and an aptitude test as well as an interview (International Federation of Library Associations and Institutions 1994: 61-62; Kaniki 1995: 23). This difference in general admission requirements for first level LIS education and training programmes between the two types of higher education institutions (that is, universities and technikons) has important implications for current debates on articulation between programmes of the two types of institutions.

As mentioned earlier, SAILIS in its 1987 Standards for education for library and information science recognised a paraprofessional level in LIS education and training. Besides providing "Standards for the education of professional staff", 
this document also provided "Standards for the training of paraprofessional staff" (South African Institute for Librarianship and Information Science 1987: I I-15). In fact in 1988 the National Diploma in Library and Information Services offered by the Cape Technikon was evaluated and accredited as a paraprofessional diploma by SAILIS' Committee for Formal Education (Van Aswegen 1997: 55, 56). Furthermore, technikon programmes were evaluated by the Certification Council for Technikon Education (SERTEC) that evaluated and accredited both the co-operative education (experiential learning) aspect as well as the formal teaching aspect of technikon LIS education and training programmes.

Libraries have traditionally had many support posts that have been occupied by a variety of types of staff ranging from clerical staff and technical staff to graduates in possession of general bachelors' degrees. According to Kerkham (1988: 10) and others who have written about LIS services in the United States of America, Canada and Australia (Bramley 1975; Hall 1985; Stieg 1992; Rochester 1997), the increasing availability of trained LIS paraprofessionals to expertly perform support tasks, especially those of a technical nature, frees the professional librarian to concentrate on professional aspects which require conceptual development and content analysis, such as building up collections, investigation of information needs, design and development of information systems, and evaluation of systems and services.

The distinction between the professional who engages in tasks that require conceptual development and the paraprofessional who engages in tasks that require application of given concepts, is often alluded to in the literature (Bowman 1988; Kerkham 1988, Nettlefold 1989; Horton 1990; Weihs 1997). Over the years there have been specific documents (both local and international) that have attempted to distinguish between professional and paraprofessional LIS services tasks. For example, at the international level, there were the Guidelines for the education of library technicians developed in 1982 by the Canadian Library Association, Professional and non-professional duties in libraries developed in 1974 by the Library Association in the United Kingdom, Descriptive list of professional and non-professional duties in libraries developed in as early as 1948 by the American Library Association and the Work level guidelines for librarians and library technicians developed in 1986 by the Library Association of Australia. Presumably all of these documents have over the years been updated to accommodate changes taking place in the field. Although Rochester (1997: 207) has pointed out that there is a considerable overlap of tasks between professionals and paraprofessionals in the LIS services workplace, these and other similar documents have been useful in providing guidelines to distinguish between the work of professionals and paraprofessionals in the LIS services workplace as well as in LIS education and training of professionals and paraprofessionals.

In South Africa, Le Roux (1985) under the guidance of SAILIS' Committee for Education and Research compiled Guidelines for distinguishing between professional and non-professional work and staff in library and information services. This document views the "nature of the thought processes and insight that are needed to carry out the work" as the criterion that distinguishes professional work and paraprofessional work:

The work is professional where action, thought and interpretation are undertaken, which to be successful, requires the worker to have an academic background and knowledge and understanding of the objective to be achieved.

The work is paraprofessional...where the action, thought and interpretation are undertaken within the limits of previously established rules, regulations and procedures (Le Roux 1985: 2)

Hence, according to Le Roux professional LIS services staff possess a professional knowledge of the principles of librarianship and information science, of the principles, theories and techniques which are applicable to any library and information service, and of the expert provision of professional services. Paraprofessional LIS services staff possess knowledge of and are skilled in the prescribed functions, services, practices and procedures of the library and information service in which they work.

The SAILIS 1987 Standards for education for library and information science reiterates this by stating that:

Training programmes [for paraprofessional LIS staff] shall be so devised that students, having completed their training, should be competent to apply standard techniques, methods and procedures in operational environments, and to handle standard systems and apparatus.

(South African Institute for Librarianship and Information Science 1987: 13)

The point needs to be made here that it is clear from the above documents that both professional and paraprofessional categories of staff are critical to a LIS service. One cannot exist without the other, as one cannot have doctors without nurses (and vice versa) in a hospital service. This means that it is important that there are institutions that provide education and training for each of these categories of staff.

Kerkham (1988: 9) points out that an important development for job appointment purposes was the evaluation of the National Diploma in Library and Information Services by the Human Sciences Research Council (HSRC) as senior certificate (or matriculation) plus three years education and training in LIS $(M+3)$. This meant that this National Diploma was recognised as being on par with any other National Diploma, and the diplomates should therefore be appointed on 
the same rank and salary scale as other technicians with National Diplomas in, for example, art, horticulture, chemistry and engineering. However, technikon LIS diplomates seem to have experienced difficulties in LIS services employers seeing the National Diploma as a paraprofessional qualification with a distinct career path for the holder of the qualification as library technician qualifications are viewed in other parts of the world such as the United States of America, Canada and Australia (Bramley 1975; Bowman 1988; Oberg 1992; Rochester 1997). For example, Van Aswegen (1997: 54) reports that an alumni survey conducted in the early 1990s by the Department of Library and Information Studies at the Cape Technikon, revealed that despite the HSRC evaluation, most libraries had no separately designated post descriptions for LIS technikon diplomates, and technikon diplomates found themselves working "'below stairs' as it were, on a par with library assistants in possession of a senior certificate [school leaving certificate]", with one or two salary notches to compensate for three years training, and few prospects for promotion beyond that of senior library assistant.

It is crucial to point out Kerkham's (1988: 8) view that paraprofessionalism in LIS services should be seen as a "parallel career option" and not "per se a step in the direction of professionalism". According to Kerkham, in the library context, the paraprofessional is commonly called a library technician, who performs a supporting role alongside the professional librarian. As in other paraprofessional fields, there should be possibilities for advanced studies, but such advanced qualifications do not turn the library technician into a professional librarian; rather, he or she would become a highly skilled technologist. Kerkham's reasoning here is very much in line with the purpose of technikon education stated at the time of the establishment of technikons in South Africa. The technikon's main educational task is to provide education and training in order to supply the labour market with middle-level and high-level personnel who possess particular skills and technological and practical knowledge that ensure that they practice their occupations effectively and productively (Department of National Education, National Education Policy Branch 1988: 22). Apart from the fact that technikons have recently been renamed Universities of Technology (Republic of South Africa 2003), the author has not found evidence of a revision of this purpose statement in subsequent documentation and therefore assumes that it still applies today. This assumption is supported by the more recent National plan for higher education (Ministry of Education 200I), which comments that technikons are currently contributing significantly to the human resource needs of the country. The Ministry therefore proposes to continue to recognise, in the short-to-medium term, "the broad function and mission of universities and technikons as two types of institutions offering different kinds of higher education programmes" (Ministry of Education 200I: 5I-52). The Minister of Education subsequently announced that "universities and technikons should in general continue to render their services to society within the bounds of the broad role-definitions and functional differentiations that have characterised their development historically" (Republic of South Africa 2002).

Horton (1990: 3) in proposing a structure for the library and information profession in South Africa had a similar vision to Kerkham. He put forward that the profession should not be seen as a hierarchical structure going vertically from the lower levels of the paraprofessional to the higher levels of advanced doctoral degrees, with the ultimate goal of everyone climbing as high up the ladder as possible. Rather the structure of the library and information profession should be seen as categories of parallel vertical structures. Within most parallel structures there is a vertical progression which some will aspire to climb as high as necessary to reach their level of maximum effectiveness.

Thus it is very important, in the author's opinion and as expressed elsewhere as well (Raju 2004a), that these two alternative or parallel career paths (that is, LIS professionalism and paraprofessionalism) should be seen in terms of a division of labour, each with its own career path or progression, and not in terms of superiority and inferiority. It is for this reason that the author's earlier analogy of doctors and nurses is useful. Both categories of staff are essential in a service, one cannot do without the other but each category has its own career path to be pursued. (However, there should be possibilities for articulation between the two career paths at the education and training level.)

The alumni survey referred to by Van Aswegen (1997) revealed that most LIS services employers did not have the post descriptions and salary structures to accommodate the National Diploma qualification. Only a few libraries had proactively instituted special post designations such as Assistant Librarian and Professional Assistant to accommodate technikon diplomates. Mhlongo (1998: i) too, in her study on the preparedness of technikon trained LIS diplomates, found that diplomates were "under-utilised" in the LIS services work environment as they were not performing tasks for which they had been trained, indicating a reluctance on the part of LIS services employers "to afford diplomates the opportunity of undertaking paraprofessional tasks". Van Aswegen also points out that the paraprofessional designation 'library technician' which is well established in the United States of America, Canada, Australia and in other parts of the world is not in common use in LIS services in South Africa.

LIS services employers, in the author's opinion, need to understand that LIS professionalism and paraprofessionalism should be seen in terms of a division of labour, each with its own career path or progression. Once clarity is achieved on 
this then they are more likely to see technikon diplomates as paraprofessionals for whom possibly distinct paraprofessional positions may need to be established in LIS services.

The Technikons Act (Act 125 of 1993) established technikons as degree-awarding institutions. In 1996 certain technikons were granted permission by SERTEC to offer the B.Tech. (Baccalaureus Technologiae) in Library and Information Studies as well as masters' and doctoral degrees in library and information studies. These higher degrees replaced the old National Higher Diploma (M+4, that is, matriculation plus four years education and training in LIS), Master's Diploma in Technology $(M+5)$ and the Laureatus in Technology $(M+6)$. These new developments once again involved re-curriculation with some technikon LIS departments, "given the large intake of students from previously disadvantaged communities, opting to offer the preliminary National Certificate $(M+I)$ and the National Higher Certificate (M+2)" (Van Aswegen 1997: 56, 57). The traditional technikon National Diploma remained as the M+3 qualification. Students therefore have the option of exiting with a paraprofessional qualification after one, two or three years of study. Admission requirements for the B.Tech. in Library and Information Studies is generally a minimum of sixty percent in each of the major final-year National Diploma subjects.

SAILIS' Committee for Formal Education, in its Proposed guidelines for undergraduate career training (1996), makes an oblique reference to the four-year technikon degree as a professional qualification. The 1996 Guidelines state quite directly that the National Certificate, the National Higher Certificate and the National Diploma are paraprofessional qualifications offered by technikons. With regard to professional qualifications it states: "For a professional bachelor's degree at a university or a technikon a study course equivalent to at least four years' full-time study is required" (South African Institute for Librarianship and Information Science 1996: I). This acknowledgement, though indirect, does represent a change in position from the 1987 SAILIS Standards that was quite clear that professional qualifications in LIS education and training must be offered at a university. For the author it also represents the ongoing lack of clarity on the issue that paraprofessionalism has its own career progression parallel to professionalism but not in the direction of professionalism as pointed out by Kerkham and Horton above and also implied in the official statement of the purpose of technikon education and training vis-á-vis university education and training. That is:

The technikon concentrates on (a) training in and practice of technology (including development), and (b) the specific side of the spectrum of vocational preparation [that is, preparation for specific occupations]. The university concentrates on (a) training in and practice of science [in the broad sense of the word which includes all scholarly activities] (including research), and (b) mainly the general side of the spectrum of vocational preparation.

(Department of National Education, National Education Policy Branch 1988: 22-23) ${ }^{1}$

However, the Committee for Formal Education that was responsible for compiling the 1996 Guidelines is careful to point out that the guidelines should not be regarded as education and training standards for library and/or information science. They should be seen as general guidelines for achieving academic excellence in education and training units.

The 1996 Guidelines perpetuates the so-called 'uncertainty' regarding the four-year technikon qualification. This 'uncertainty' has been referred to by the author elsewhere (Raju 2004a), where the author interprets this 'uncertainty' as a lack of clarity among many on the issue of professionalism and paraprofessionalism each having their own career progressions. This 'uncertainty' is evident in Underwood and Nassimbeni's comment (1996: 219) that "it is unclear whether some employers, such as universities, will be willing to appoint people who have obtained the National Higher Diploma [now replaced by the B.Tech.], but do not have university degrees, to professional posts". As pointed out earlier the university degree has traditionally, and in keeping with international trends, been the requirement for appointment to professional posts in this country.

Stilwell (1997: 209) makes reference to current debates of how "technikon diplomates can gain access to [university] honour's and master's degrees" and about "equating...the B.Tech. with the B.Bibl. and the B degree and post-graduate diploma", thus making reference to issues of articulation between university and technikon LIS programmes. According to Underwood and Nassimbeni (1996: 219) these problems of vertical and horizontal mobility are experienced across many academic disciplines and professional areas of study with the result that in the absence of "an agreed upon system of modular credits, accreditation and the ability to use credits gained for courses completed elsewhere, students tend to find themselves 'locked in' to a particular package of courses offered by one institution". It is hoped that these unresolved issues of recognition of qualifications, accreditation and articulation between different types of higher education institutions would be resolved by current attempts to develop a single co-ordinated system of higher education in South

I. The author would like to reiterate that she has not been able to find in subsequent official documentation any evidence of revision of these purpose statements. In fact, to date, this seems to be the only official document that discusses, in some detail, technikon education and training vis-á-vis university education and training. 
Africa that brings together universities, technikons, colleges and private providers of higher education, and will facilitate recognition of qualifications, accreditation and student mobility between different types of higher education institutions within a National Qualifications Framework (South African Qualifications Authority 1997).

\section{Conclusion}

These discussions have, hopefully, brought up-to-date the historical development of LIS education and training in South Africa (as well as the issues associated with this development), particularly the involvement of technikons as well as how changes in the post-1990 era in South African society generally and in the higher education sector specifically, have impacted on LIS education and training. Some of the important issues associated with this development, such as, differentiation and specialisation in LIS education and training, the relationship between university and technikon LIS education and training, and articulation between LIS programmes offered by different types of higher education institutions, need to be further researched with a view to possibly guiding these important developments. The author has already to some extent researched and made recommendations on the issue of the relationship between university and technikon LIS education and training (Raju 2002; Raju 2004a; Raju 2004b). The same needs to be done with other important issues associated with the historical development of LIS education and training in South Africa. To this end the author has provided in the appendix to this article a chronology of historical events associated with LIS education and training in South Africa.

\section{References}

Bowman, R.J. 1988. Library technicians under and over. Canadian library journal, 45(4): 229-233.

Bramley, G. 1975. World trends in library education. London: Clive Bingley.

Brink, J.A. 199I. The CUP rationalisation programme and the offering of librarianship at universities. SAILIS newsletter, I I(6): 5 , 7.

Bunting, I.A. 1990. Librarianship and the rationalisation of South African universities. In Nassimbeni, M. and de Jager, K. eds. The future of library and information science : social, technological and educational challenges : proceedings of the $50^{\text {th }}$ Anniversary Symposium of the School of Librarianship, University of Cape Town, 20-2I November 1989. pp.53-66. Cape Town: University of Cape Town.

Committee of University Principals (CUP). 1990. Review of librarianship : final report. s.I.: CUP.

Department of National Education, National Education Policy Branch. 1988. A philosophy for technikon education (NATED 02I 18). Pretoria: Department of National Education.

Hall, J. 1985. Training library professionals. Journal of European industrial training, 9(I): 9-12.

Horton, W.J. 1990. The structure of the information profession in South Africa : the development of a rational pattern : inaugural lecture. Pietermaritzburg: University of Natal Press.

International Federation of Library Associations and Institutions (IFLA). 1994. Education, training, and employment of library and information professionals in South Africa. Journal of education for library and information science, 35(I): 6I-63.

Kaniki, A.M. 1995. Library and information science education and training for information provision to rural communities in South Africa. Quarterly bulletin of the International Association of Agricultural Librarians and Documentalists, 40(I): 21 -29.

Kerkham, A.S. 1986. Address on technikon diplomas : certain false impressions created. SAILIS newsletter, 6(I2): 3.

Kerkham, A.S. 1988. The education of library technicians in South Africa. South African journal of library and information science, 56(I): 7-10.

Le Roux, H.S. 1985. Guidelines for distinguishing between professional and non-professional work and staff in library and information services. Pretoria: SAILIS, Committee for Education and Research.

Library and Information Association of South Africa (LIASA). 1997. The birth of LIASA. The LIASA letter : official newsletter of the Library and Information Association of South Africa, I (I): I.

Manaka, S. 1990. Library education in Southern Africa. In Wise, M. and Olden, A. eds. Information and libraries in the developing world : I. Sub-Saharan Africa. pp. 25-46. London: The Library Association.

Mhlongo, M.A. 1998. The preparedness of technikon-trained library and information science diplomates for the work situation : an evaluative study. MIS thesis, University of Natal, Pietermaritzburg.

Ministry of Education. 200 I. National plan for higher education. Visited on 07/03/200 I at: http://education.pwv.gov.za/doe-sites/h.../national/plan/final/draft.ht

Ministry of Education. 2002. Approved academic programmes for universities and technikons : 2003-2006. Pretoria: Department of Education.

Musiker, R. 1986. Companion to South African libraries. Craighall: Ad. Donker.

Nassimbeni, M. 1988. The imperative for change : curriculum revision in South Africa. Education for information, 6: 153-185.

Nassimbeni, M., Stilwell, C. and Walker, C. 1993. Education and training for library and information work : an analysis of the current South African situation with a view to the way forward. Innovation, 6: 30-44.

National Education Policy Investigation (NEPI). 1992. Library and information services : report of the NEPI Library and Information Services Research Group : a project of the National Education Co-ordinating Committee. Cape Town: Oxford University Press.

Nettlefold, B.A. 1989. Paraprofessionalism in librarianship. International library review, 21: 519-531.

Oberg, L.R. 1992. The emergence of the paraprofessional in academic libraries : perceptions and realities. College and research libraries, 53(2): 99-II 2.

Ocholla, D. 2000. Training for library and information studies : a comparative overview of LIS education in Africa. Education for information, 18: 33-52. 
Raju, J. 2002. First level library and/or information science qualifications at South African universities and technikons : a comparative study of curricula. PhD thesis, University of Natal, Pietermaritzburg.

Raju, J. 2004a. First level library and/or information science qualifications at South African universities and technikons : a comparative study of curricula. South African journal of libraries and information science, 70(1): 9-19.

Raju, J. 2004b. General education in library and/or information science education and training. Education for information, 22: I21.

Republic of South Africa. 2002. Transformation and restructuring : a new institutional landscape for higher education. [government gazette no. 855]. Pretoria: Government Printer.

Republic of South Africa. 2003. Higher Education Act, 1997 (Act No. 101 of 1997): merger of public higher education institutions [government gazette nos. 25737 and 25787]. Pretoria: Government Printer.

Rochester, M.K. 1997. Education for librarianship in Australia. London: Mansel.

Rosenberg, D. 1999. An overview of education for librarianship in Anglophone Sub-Saharan Africa. In Wise, M. ed. Education for librarianship and information science in Africa. pp. I I-33. Stockholm, Sweden: Uppsala University Library.

South African Institute for Librarianship and Information Science (SAILIS). 1987. Standards for education for library and information science. Updated ed. s.l.: SAILIS.

South African Institute for Librarianship and Information Science (SAILIS). 1996. Proposed guidelines for undergraduate career training. s.l.: SAILIS.

South African Qualifications Authority (SAQA). 1997. The emergence of the NQF and SAQA. South African Qualifications Authority bulletin, I: [1-20].

Stieg, M.F. 1992. Change and challenge in library and information science education. Chicago ; London: ALA.

Stilwell, C. 1997. First professional, in-service and continuing education and training : provincial library perceptions. South African journal of library and information science, 65(4): 207-217.

Underwood, P.G. 1996. LIS education in South Africa : the advance from neutrality. The Library Association record, 98(3): I46148.

Underwood, P.G. and Nassimbeni, M.C. 1996. First steps : reconstructing library and information science education in South Africa. Education for information, 14: 215-223.

Underwood, P.G. and Nassimbeni, M.C. 1999. We shall all be changed : professional development and training in the Republic of South Africa. In Wise, M. ed. Education for librarianship and information science in Africa. pp. I79-196. Stockholm, Sweden: Uppsala University Library.

Van Aswegen, E.S. 1992. Cape Technikon : the National Diploma in Library and Information Practice. Cape librarian, 36(I0): 2021.

Van Aswegen, E.S. 1997. Menials or managers? : a decade of library and information science education at the Cape Technikon. South African journal of library and information science, 65(I): 53-59.

Van Brakel, P.A. 1992. Aspects regarding the educational structure of LIS training at South African universities. South African journal of library and information science, 60(3): 188-193.

Weihs, J.R. 1997. Technical services education for library technicians in the 1990s. Technical services quarterly, 15(1/2): 43-50.

Zaaiman, R.B. 1985. The information society in South Africa : an exploratory study. South African journal of library and information science, 53: 129-138.

\section{Appendix}

\section{Chronology of historical events associated with LIS education and training in South Africa}

1933 SALA introduced correspondence courses for the training of librarians following recommendations made by Carnegie Corporation commissioners S.A. Pitt and M.J. Ferguson.

1938 University of Pretoria became the first university in South Africa to offer a programme in librarianship. Other universities followed.

1955 University of South Africa (UNISA) began correspondence programmes in librarianship.

1962 The professional body (SALA) transferred responsibility for correspondence courses to UNISA.

1979 SALA's Committee for Education and Research developed the Standards for library and information service (used by universities in curriculum development of librarianship programmes).

1984 A three-year technikon national diploma in LIS was first offered by Port Elizabeth Technikon. Other technikons followed.

1985 H.S. le Roux, under the guidance of SAILIS' Committee for Education and Research, compiled Guidelines for distinguishing between professional and non-professional work and staff in library and information services.

1987 SAILIS (previously SALA) issued the Standards for education for library and information science which replaced the 1979 standards.

1988 Committee of University Principals (CUP) undertook a national review of academic programmes in librarianship and information science.

1990 CUP released the final report of the review committee (Bunting Report) which recommended the closure of some LIS programmes and the curtailment of others. 
1992 The Library and Information Services Research Group of NEPI (National Education Policy Investigation) highlighted shortcomings in LIS education and training in South Africa.

1993 The Technikons Act (Act 125 of 1993) established technikons as degree-awarding institutions.

1996 Certain technikons were granted permission by SERTEC (technikons' national accreditation body) to offer the B.Tech. in library and information studies as well masters' and doctoral degrees in this field.

1996 SAILIS issued its Proposed guidelines for undergraduate career training.

1997 LIASA was launched as the new professional body in the LIS sector in South Africa, following the dissolution of SAILIS. However, accreditation of LIS programmes, previously done by the professional body, remained in abeyance pending the operations of the newly constituted SAQA and its related structures (NQF, SGBs, NSBs, ETQAs).

200 I Ministry of Education releases its National plan for higher education aimed at restructuring the higher education system in South Africa to overcome inequalities and inefficiencies of the past.

2002 Ministry of Education issues the Approved academic programmes for universities and technikons : 2003-2006 that called for a review of academic programmes that are duplicated in certain regions, for example LIS programmes in KwaZulu Natal. 